\title{
Interactive comment on "Effects of Multiple Doppler Radar data assimilation on the numerical simulation of a Flash Flood Event during the HyMeX campaign” by Ida Maiello et al.
}

Ida Maiello et al.

ida.maiello@aquila.infn.it

Received and published: 10 November 2016

The comment was uploaded in the form of a supplement:

http://www.hydrol-earth-syst-sci-discuss.net/hess-2016-320/hess-2016-320-AC3-

supplement.pdf

Interactive comment on Hydrol. Earth Syst. Sci. Discuss., doi:10.5194/hess-2016-320, 2016. 